\title{
Transient Effectiveness of an Oral 5-Fluorouracil Derivative, S-1, for Epirubicin, Cyclophosphamide and Paclitaxel Refractory Skin Metastases from Possible Occult Breast Cancer in a Male
}

\author{
Ayaka Hirao $^{\mathrm{a}}$ Naoki Oiso $^{\mathrm{a}} \quad$ Junji Tsurutani ${ }^{\mathrm{b}}$ Masatomo Kimura $^{\mathrm{c}}$ \\ Masahiro Watatani ${ }^{d}$ Kazuhiko Nakagawa ${ }^{b}$ Akira Kawada $^{a}$
}

Departments of a Dermatology, ${ }^{b}$ Medical Oncology, cPathology, and ${ }^{\mathrm{d} S u r g e r y,}$

Kinki University Faculty of Medicine, Osakasayama, Japan

\section{Key Words}

Occult breast cancer $\cdot$ Skin metastases $\cdot$ S-1

\begin{abstract}
Recent chemotherapies for skin metastases from breast cancer have shown to be effective for regression, disappearance, and favorable quality of life. We describe the case of a 76-year-old male showing transient effectiveness with an oral 5-fluorouracil derivative, S-1 (tegafur, 5-chloro-2,4-dihydroxypyridine and potassium oxonate), for epirubicin, cyclophosphamide and paclitaxel refractory skin metastases from possible occult breast cancer. The male patient was initially diagnosed as having lymph node metastases in the left axilla as possible occult breast cancer. The skin metastases developed after chemotherapy with a combination of epirubicin and cyclophosphamide, subsequent chemotherapy with paclitaxel, and radiotherapy. Chemotherapy with paclitaxel was resumed for skin metastases, but it was not effective. Alternative chemotherapy with the oral agent S-1 was administered. The skin metastases completely disappeared after the second course, but recurred at the end of the third course. This case suggests that S-1 may be a candidate for chemotherapy for skin metastases from occult breast cancer in males.
\end{abstract}

\section{Introduction}

Breast cancer in a male is very rare, comprising less than $1 \%$ of all breast cancers and less than $1 \%$ of all cancers in men $[1,2]$. The occurrence of occult breast cancer in a male 
is even rarer, although some cases have been reported [3, 4]. Here, we report a male having epirubicin, cyclophosphamide and paclitaxel refractory skin metastases from possible occult breast cancer. The skin metastases transiently disappeared completely following a chemotherapy with an oral 5-fluorouracil (5-FU) derivative, S-1 (tegafur, 5chloro-2,4-dihydroxypyridine (CDHP) and potassium oxonate; Taiho Pharmaceutical Co. Ltd., Tokyo, Japan).

\section{Case Report}

A 76-year-old Japanese man presented to our department with asymptomatic eruptions. The initial examination revealed asymptomatic erythematous patches and linear macules, which were gradually increasing in size and number on the left chest and back (fig. 1a). The patient had had an edematous swelling on the left arm and a palpable lymph node on the left axilla 1.5 years earlier. Lymph nodes, except the left axilla, had not been palpable. A chest X-ray had been clear. A positron emission tomography (PET)/computed tomography (CT)-scan of the entire body had shown only enlarged lymph nodes in the left axilla and had not depicted any other lesions. The lymph nodes in the left axilla had been excised surgically. Tumor cells were detected in 9 out of 30 lymph nodes. Immunohistochemical staining showed positive reaction to gross cystic disease fluid protein-15 (GCDFP-15) and mammaglobin, and negative reaction to human epithelial growth factor receptor type 2 (HER2), estrogen receptor (ER), and progesterone receptor (PgR). The patient had been diagnosed as having lymph node metastases from possible occult breast cancer. He had received chemotherapy consisting of epirubicin $25 \mathrm{mg} / \mathrm{m}^{2}$ and cyclophosphamide $100 \mathrm{mg} /$ body once a week for 18 courses, following chemotherapy with paclitaxel $80 \mathrm{mg} / \mathrm{m}^{2}$ once a week for 14 courses, and then he had been given radiotherapy consisting of electron radiation, 2 Gy per irradiation (total 30 times, $60 \mathrm{~Gy}$ ), on the left upper chest, axilla and back.

Histopathological examination of a biopsy specimen revealed an extensive invasion of the dermal lymphatics by groups and cords of tumor cells (fig. 1b). The cells were similar to those in the lymph nodes in the left axilla. Morphologically, they were irregular in size and shape, with large, pleomorphic and hyperchromatic nuclei (fig. 1d). Immunohistochemical staining showed positive reaction to GCDFP-15, and negative reaction to mammaglobin, HER2, ER and PgR. The erythematous patches and linear macules were diagnosed to be skin metastases from possible occult breast cancer. Systemic examination showed no enlarged lymph nodes or focal lesions except skin involvement.

Chemotherapy with paclitaxel was resumed. The regimen was the same as in the previous treatment $\left(80 \mathrm{mg} / \mathrm{m}^{2}\right.$ once a week). At the end of the 5 courses, we concluded that the chemotherapy was not effective for the metastatic cancer. The erythematous patches and linear macules grew into a painful large dark reddish patch and necrotic nodules (fig. 1c).

An alternative chemotherapy with S-1 (tegafur $120 \mathrm{mg}$, CDHP $34.8 \mathrm{mg}$, potassium oxonate 117.6 $\mathrm{mg}$ ) was administered orally. A regime was established consisting of oral administration of S-1 for 28 days followed by an intermission of 14 days. Complete disappearance was achieved, when 2 courses were given. The lesion showed pigmented macules and an ulcer, $40 \times 30 \mathrm{~mm}$ in size, with no pain (fig. 2a). A spindle biopsy from the border of the ulcerated lesion was taken for histopathological evaluation. The specimen revealed a massive infiltration of inflammatory cells in the dermis, dilated vessels, and extravessel erythrocytes (fig. 2b). The infiltrated cells were intermingled with plasma cells, lymphocytes and histiocytes (fig. 2c).

However, 2 elastic hard papules, $5 \times 5 \mathrm{~mm}$ in size, developed on the previously affected lesion after the end of the third course of the S-1 administration (fig. $3 a$ ). A biopsied specimen from a papule showed tumor cells that were morphologically irregular in size and shape with large, pleomorphic and hyperchromatic nuclei (fig. 3b, c). Immunohistochemical staining showed positive reaction to GCDFP15 and negative reaction to mammaglobin, HER2, ER and PgR. 


\begin{tabular}{r|l|l|l}
$\begin{array}{c}\text { Case Reports in } \\
\text { Dermatology }\end{array}$ & $\begin{array}{l}\text { Case Rep Dermatol 2011;3:42-48 } \\
\text { DOI: } 10.1159 / 000325069\end{array}$ & $\begin{array}{l}\text { Published online: } \\
\text { February 23, 2011 }\end{array}$ & $\begin{array}{l}\text { O 2011 S. Karger AG, Basel } \\
\text { ISSN 1662-6567 } \\
\text { www.karger.com/cde }\end{array}$ \\
\hline
\end{tabular}

\section{Discussion}

The skin lesion was diagnosed as skin metastases from possible occult breast cancer. Occult breast cancer commonly presents lymph node metastasis of the axilla, supraclavicular fossa and infraclavicular fossa as first manifestation $[4,5]$. One differential diagnosis is primary carcinoma of an accessory mammary gland. The histopathological specimen is characterized by the presence of sweat glands, sebaceous glands, and connective tissue [6].

Chemotherapy consisting of epirubicin and cyclophosphamide is commonly given as the first-line therapy for metastatic breast cancer. Taxanes, such as paclitaxel, are used in early-stage breast cancer and in first-line therapy for metastatic breast cancer [7]. Treatment of taxane-refractory disease is challenging and newer agents are being developed for clinical application [7]. S-1 is an oral fluoropyrimidine formulation that combines tegafur, CDHP, and potassium oxonate in a molar ratio of 1:0.4:1 [8]. CDHP inhibits an enzyme that metabolites 5-FU, dihydropyrimidine dehydrogenase [9]. Therefore, high 5-FU concentrations are maintained, and S-1 may be effective in patients who do not respond to other fluoropyrimidine agents [9]. Potassium oxonate can reduce gastrointestinal toxicities, which are the main adverse events of 5-FU agents [9]. Single agent $\mathrm{S}-1$ has demonstrated marked activity against a broad array of solid tumors, including breast, gastric, colorectal, cervical, pancreatic, and lung cancers [8]. The strategy for treating metastatic breast cancer is to maintain favorable quality of life and to improve survival [9]. S-1 may be a valuable agent for metastatic and recurrent breast cancer because it shows clinical efficacy and mild toxicity and can be given orally [9]. A randomized controlled trial is currently comparing S-1 with standard chemotherapies, such as taxanes, in women with metastatic or recurrent breast cancer [10]. In the present case, temporal complete disappearance was achieved. We believe that the administration of S-1 temporarily kept the patient in a comfortable condition and improved the period of survival.

In summary, we described the case of a male patient with skin metastases from possible occult breast cancer. S-1 may be a candidate for chemotherapy for skin metastases from breast cancer in males. 


\begin{tabular}{l|l|l|l}
$\begin{array}{c}\text { Case Reports in } \\
\text { Demillatology }\end{array}$ & $\begin{array}{l}\text { Case Rep Dermatol 2011;3:42-48 } \\
\text { DOI: } 10.1159 / 000325069\end{array}$ & $\begin{array}{l}\text { Published online: } \\
\text { February 23, 2011 }\end{array}$ & $\begin{array}{l}\text { I 2011 S. Karger AG, Basel } \\
\text { ISSN 1662-6567 } \\
\text { www.karger.com/cde }\end{array}$ \\
\hline
\end{tabular}


Fig. 1. a Clinical image of erythematous patches and linear macules on the left chest and back. b, d A biopsied specimen from an erythematous linear macule. HE, original magnification, $\times 100(\mathbf{b}), \times 400(\mathbf{d})$. c Clinical image of a large dark reddish patch with necrotic nodules after 5 courses of resumed chemotherapy with paclitaxel. 


\begin{tabular}{c|l|l|l}
$\begin{array}{c}\text { Case Reports in } \\
\text { Demlilatology }\end{array}$ & $\begin{array}{l}\text { Case Rep Dermatol 2011;3:42-48 } \\
\text { DOl: } 10.1159 / 000325069\end{array}$ & $\begin{array}{l}\text { Published online: } \\
\text { February 23, 2011 }\end{array}$ & $\begin{array}{l}\text { O 2011 S. Karger AG, Basel } \\
\text { ISSN 1662-6567 } \\
\text { www.karger.com/cde }\end{array}$ \\
\hline
\end{tabular}
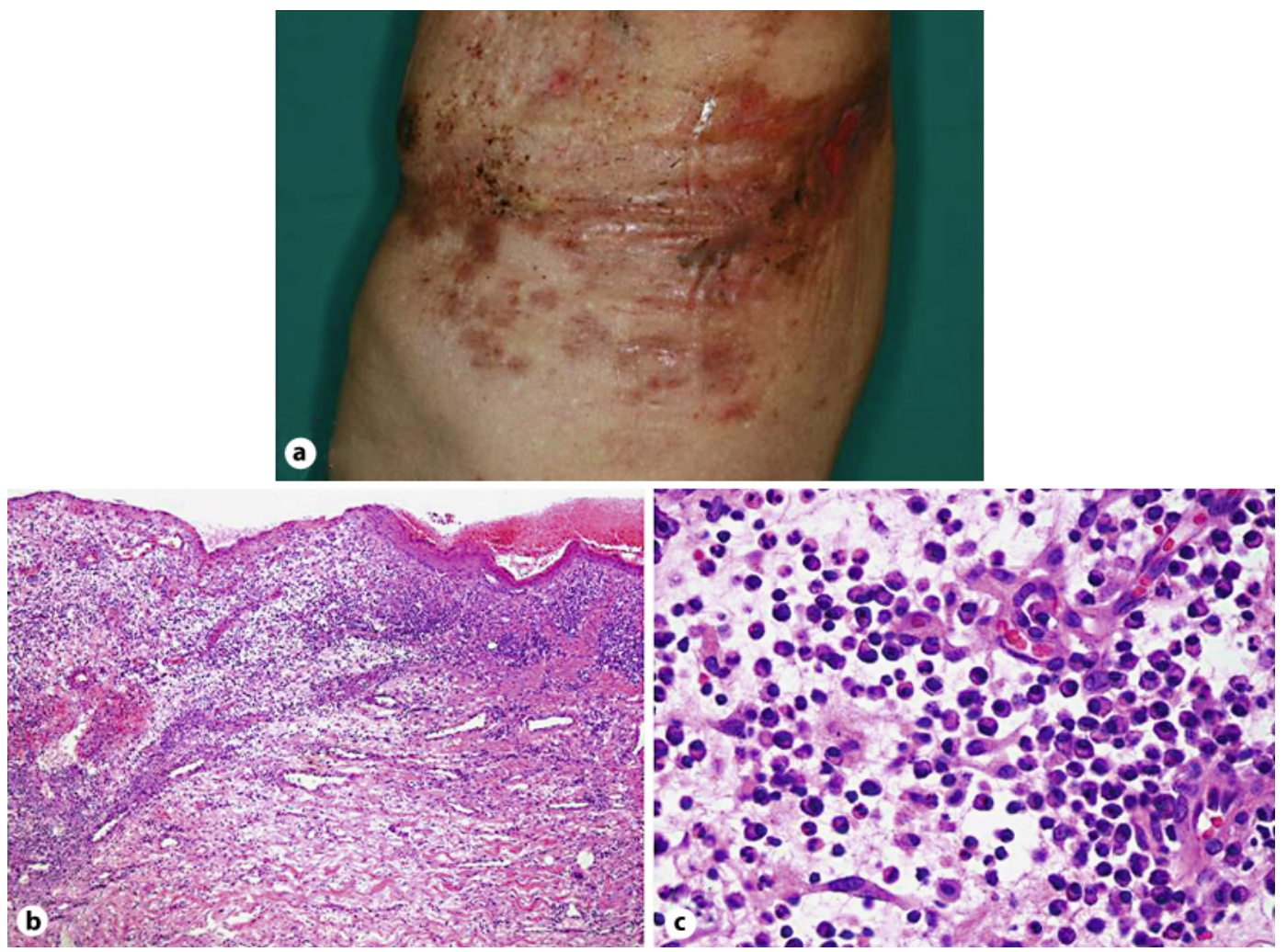

Fig. 2. a Clinical image of complete disappearance of the metastatic skin lesion after 2 courses of S-1 therapy. b, c A biopsied specimen from the border of the ulcer. HE, original magnification, $\times 100$ (b), $\times 400$ (c). 


\begin{tabular}{c|l|l|l}
$\begin{array}{c}\text { Case Reports in } \\
\text { Demlilatology }\end{array}$ & $\begin{array}{l}\text { Case Rep Dermatol 2011;3:42-48 } \\
\text { DOl: } 10.1159 / 000325069\end{array}$ & $\begin{array}{l}\text { Published online: } \\
\text { February 23, 2011 }\end{array}$ & $\begin{array}{l}\text { O 2011 S. Karger AG, Basel } \\
\text { ISSN 1662-6567 } \\
\text { www.karger.com/cde }\end{array}$ \\
\hline
\end{tabular}


Fig. 3. a Clinical image of 2 elastic hard papules, $5 \times 5 \mathrm{~mm}$ in size, that recurred after the end of the third course of the S-1 administration. b, c A biopsied specimen from a papule. HE, original magnification, $\times 100(\mathbf{b}), \times 400(\mathbf{c})$. 


\section{References}

1 Giordano SH: A review of the diagnosis and management of male breast cancer. Oncologist 2005;10:471-479.

- Giordano SH, Buzdar AU, Hortobagyi GN: Breast cancer in men. Ann Intern Med 2002;137:678-687.

-3 Namba N, Hiraki A, Tabata M, Kiura K, Ueoka H, Yoshino T, Tanimoto M: Axillary metastasis as the first manifestation of occult breast cancer in a man: a case report. Anticancer Res 2002;22:3611-3613.

4 Gu GL, Wang SL, Wei XM, Ren L, Zou FX: Axillary metastasis as the first manifestation of male breast cancer: a case report. Cases J 2008;1:285.

5 Burga AM, Fadare O, Lininger RA, Tavassoli FA: Invasive carcinomas of the male breast: a morphologic study of the distribution of histologic subtypes and metastatic patterns in 778 cases. Virchows Arch 2006;449:507512.

-6 Takeyama H, Takahashi H, Tabei I, Fukuchi O, Nogi H, Kinoshita S, Uchida K, Morikawa T: Malignant neoplasm in the axilla of a male: suspected primary carcinoma of an accessory mammary gland. Breast Cancer 2010;17:151-154.

7 Amar S, Roy V, Perez EA: Treatment of metastatic breast cancer: looking towards the future. Breast Cancer Res Treat 2009;114:413-422.

-8 Mukai H, Takashima T, Hozumi Y, Watanabe T, Murakami S, Masuda N, Mitsuyama S, Ohmura T, Yajima T, Ohashi Y: Randomized study of taxane versus TS-1 in women with metastatic or recurrent breast cancer (SELECT BC). Jpn J Clin Oncol 2010;40:811-814.

9 Okamoto I, Fukuoka M: S-1: a new oral fluoropyrimidine in the treatment of patients with advanced nonsmall-cell lung cancer. Clin Lung Cancer 2009;10:290-294.

$\rightarrow 10$ Taira N, Aogi K, Ohsumi S, Takashima S, Nishimura R, Doihara H, Saeki T: S-1 (TS-1) maintained complete response for approximately 10 years in a case of metastatic breast cancer. Breast Cancer 2006;13:220-224. 